\title{
Multiseptate Gallbladder, a Rare Cause of Recurrent Abdominal Pain: A Case Report and Review of the Literature
}

\author{
Nadir Bir Karın Ağrısı Nedeni, Multiseptalı Safra Kesesi: Olgu Sunumu ve \\ Literatürün Gözden Geçirilmesi
}

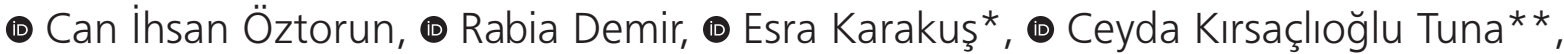 \\ ๑ Süleyman Arif Bostancı, ๑ Atilla Şenaylı, ๑ Müjdem Nur Azılı, ๑ Emrah Şenel
}

University of Health Sciences, Ankara Children's Health and Diseases, Hematology Oncology Training and Research Hospital, Clinic of Pediatric Surgery, Ankara, Turkey

*University of Health Sciences, Ankara Children's Health and Diseases, Hematology Oncology Training and Research Hospital, Clinic of Pathology, Ankara, Turkey

**University of Health Sciences, Ankara Children's Health and Diseases, Hematology Oncology Training and Research Hospital, Clinic of Pediatric Gastroenterology, Ankara, Turkey

Abstract

Multiseptate gallbladder is a rare congenital malformation. It was first described by Simon and Tandon in 1963. A 1-year-old boy was admitted to our clinic with the complaints of intermittent abdominal pain and itching. Physical examination was normal; in laboratory tests, only liver enzymes (aspartate aminotransferase: $442 \mathrm{U} / \mathrm{L}$, alanine aminotransferase: $270 \mathrm{U} / \mathrm{L}$ ) and gamma glutamyl transpeptidase (73 U/L) were elevated. Ultrasonography (USG) showed a multiloculated gallbladder measuring approximately $41 \times 33 \times 46 \mathrm{~mm}$ in size with structures of septation with echogenic density contents. On magnetic resonance cholangiopancreatography (MRCP), a multiseptated cystic lesion approximately $90 \times 50 \times 80 \mathrm{~mm}$ in size was observed in the inferomedial aspect of the liver. Laparoscopic cholecystectomy was performed. Macroscopic evaluation demonstrated multiple septa dividing the gallbladder into compartments of different sizes. In the post-operative follow-up, liver enzymes fell within the normal range. Multiseptate gallbladder is a very rare congenital anomaly. In most cases, colic pain and nausea are observed. USG, computed tomography, MRCP, endoscopic retrograde cholangio-pancreatography, and hepatobiliary scintigraphy can be used in diagnosis. Cholecystectomy is preferred in the treatment of patients presenting with biliary colic. Asymptomatic cases do not require surgery; follow-up ultrasound scans are recommended. Multiseptate gallbladder should be considered in
Multiseptalı safra kesesi nadir rastlanılan konjenital bir malformasyondur. Illk kez 1963 yılında Simon ve Tandon tarafından tanımlanmıştır. Bir yaşında erkek hasta, kliniğimize ara ara olan karın ağrısı ve kaşıntı şikayetiyle başvurdu. Fizik muayene doğal olup laboratuvar testlerinde karaciğer fonksiyon testleri (aspartat aminotransferaz: $442 \mathrm{U} / \mathrm{L}$, alanin aminotransferaz: $270 \mathrm{U} / \mathrm{L}$ ) ve gama glutamil transpeptidazın (73 U/L) yüksek olduğu görüldü. Takiplerinde karaciğer fonskiyon testlerinde düşme olmayan ve kaşıntı şikayeti devam eden hastanın cerrahi konsültasyonu istendi. Ultrasonografide (USG) safra kesesi lokalizasyonunda yaklaşık $41 \times 33 \times 46 \mathrm{~mm}$ boyutlu, içinde ekojen septasyon yapıları ve multilokule yoğun içerikli safra kesesi görünümü izlenmiştir. Manyetik rezonans kolanjiopankreatografide (MRCP) karaciğer inferomedialinde yaklaşık 90×50×80 mm boyutunda multiseptalı kistik lezyon izlendi. Hastaya laparaskopik kolesistektomi yapıldı. Patolojisinde makroskopik olarak safra kesesinin farklı büyüklükte septalarla bölmelere ayrıldığı izlendi. Postoperatif takiplerinde karaciğer enzim testleri normal sınırlarına geriledi. Multiseptalı safra kesesi, safra yolunun çok nadir görülen anomalilerinden birisidir. Olguların çoğunda kolik ağrı ile birlikte bulantı olduğu görülmüştür. Tanıda USG, bilgisayarlı tomografi, MRCP, endoskopik retrograd kolanjiopankreatografi, bilier sintigrafi kullanılabilir. Bilier kolik ile başvuran olgularda tedavide kolesistektomi tercih edilir. Asemptomatik olgularda ise cerrahiye gerek yoktur, USG ile takip yapılır. Multiseptalı safra kesesi, intermitant sağ üst
Address for Correspondence/Yazışma Adresi: Can İhsan Öztorun

Ankara Yıldırım Beyazıt University Faculty of Medicine, Department of Pediatric Surgery, Ankara, Turkey

Phone: +90 5062987004 E-mail: drcan-oz@hotmail.com ORCID ID: orcid.org/0000-0002-5408-2772

Received/Geliş Tarihi: 03 May 2017 Accepted/Kabul Tarihi: 21 October 2017
Copyright 2018 by The Medical Bulletin of University of Health Sciences Haseki Training and Research Hospital

The Medical Bulletin of Haseki published by Galenos Yayınevi. 
the differential diagnosis of acute cholecystitis and cholecystitis, in patients with intermittent right upper quadrant pain.

Keywords: Multiseptate gallbladder, abdominal pain, cholecystectomy kadran ağrısı olan hastalarda, akut taşlı kolesistit ve akalkülöz kolesistit dışında ayırıcı tanıda düşünülmesi gereken nadir bir klinik durumdur.

Anahtar Sözcük: Multiseptalı safra kesesi, karın ağrısı, kolesistektomi

\section{Introduction}

Multiseptate gallbladder is a rare congenital malformation. It was first identified by Simon and Tandon (1) in 1963. Although asymptomatic patients have been reported, many patients present to the emergency department due to intermittent biliary colic. The aim of this study was to remind the pathology to pediatric physicians so that it can be considered in the differential diagnosis of cases presenting with recurrent abdominal pain, and to review the literature on this condition.

\section{Case}

A 1-year-old male presented to the pediatric outpatient department at our hospital with the complaints of recurrent abdominal pain and itching. The patient was referred to the pediatric gastroenterology department after preliminary investigations were completed. The physical findings were normal. Laboratory results revealed elevated liver function test results (aspartate aminotransferase: 442 $\mathrm{U} / \mathrm{L}$, alanine aminotransferase: $270 \mathrm{U} / \mathrm{L}$, gamma glutamyl transpeptidase: $173 \mathrm{U} / \mathrm{L}$ ). Radiologic investigation with ultrasonography (USG) showed echogenic septa in the gallbladder with a multiloculated dense content. A multiseptate cystic lesion measuring $90 \times 50 \times 80 \mathrm{~mm}$ in size inferomedial to the liver was observed on magnetic resonance cholangiopancreatography (MRCP).

The patient was followed-up as an outpatient by the pediatric gastroenterology department but was referred to the pediatric surgery department later on due to the lack of improvement in abdominal pain and laboratory values and continuation of the itching during followup. The patient was evaluated by both departments and laparoscopic cholecystectomy was performed. The gallbladder was divided into sections of various sizes, and the findings were also consistent with cholecystitis on pathology investigation (Figure 1: macroscopic view of multiseptate gallbladder).

The laboratory values of the patient returned to normal during post-operative follow-up.

We got the permission and affirmation to submit from the parents of patient presented in the case report.

\section{Discussion}

Multiseptate gallbladder is a rare congenital malformation. It is thought to be a developmental anomaly of the gallbladder. Three theories are present. Incomplete cavitation of the solid embryonic gallbladder

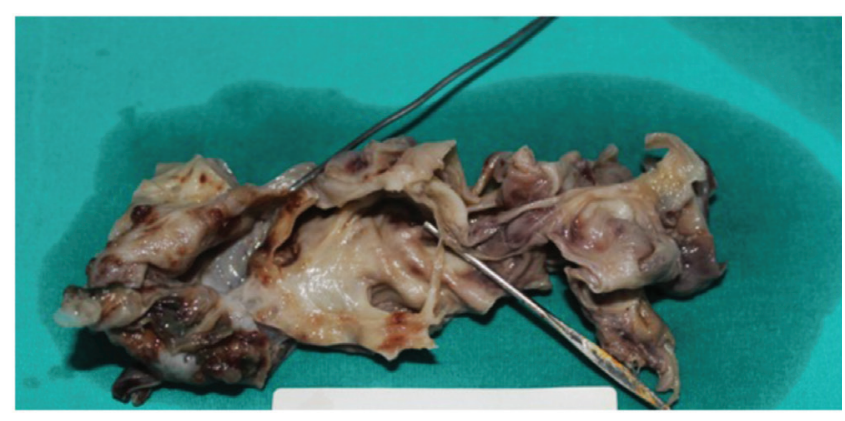

Figure 1. Macroscopic view of multiseptate gallbladder

is suggested to cause multiseptate gallbladder or stricture in the first theory. However, this theory cannot explain the presence of smooth muscle in the septa. The second theory is the Wrinkling theory and suggests that the sac has an irregular wrinkled appearance in the solid stage during embryologic development of the gallbladder and this prevents gallbladder cavity formation by combining solid intraepithelial structures. The third theory is the Phrygian cap theory and suggests that curling and flexures occur in the sac as the gallbladder develops faster than the surrounding structures such as the sac lodge and peritoneum during the developmental stages (2).

A multiseptate gallbladder is usually symptomatic in adults and especially in females. It is rare in childhood and is usually seen in school-age children. However, ectopic pancreas and multiseptate gallbladder have been reported in a 15-day-old male infant (3).

The gallbladder is divided into many sections by thin septa and honeycombing occurs in these cases. Although the septa are mostly diffuse in the reported cases, partial cases have also been reported (4).

There are multiple mechanisms that cause the development of this abnormality. Childhood cases have been reported to present mostly with biliary symptoms, and a choledochal cyst to be present in $23 \%$ of the cases in the literature (3). Symptomatic patients usually present with recurrent right upper quadrant pain. Why certain uncomplicated cases remain asymptomatic and are only discovered in imaging studies while other cases have recurrent right upper quadrant pain is not clear. There are two theories explaining the appearance of the symptoms. According to the first theory, the cause of the pain is temporary obstruction of the flow of viscous bile between the septated areas. According to the second theory, the cause of pain is increased intraluminal pressure 
and dysfunction due to irregular contractions of the gallbladder (2).

Cases of multiseptate gallbladder associated with liver enzyme elevation have previously been reported by Dalgıç et al. (5) and Paciorek et al. (6). In their study, Paciorek et al. (6) reported that the temporary liver enzyme elevation was due to temporary obstruction of the gallbladder tract.

Nausea and vomiting together with colic pain have been reported to be present in the majority of cases with symptomatic multiseptate gallbladder and such symptoms to disappear after cholecystectomy (3). Acute pancreatitis, cholelithiasis, gallbladder hypoplasia and choledochal cyst have been reported, although rarely. Gallbladder mucosa and hyperplastic cholestasis should be considered in the differential diagnosis (7). Multiseptate gallbladder and gallbladder malignancies have been reported to be associated and a gallbladder tumor has been reported in an adult patient with multiseptate gallbladder (8). While gallstones can rarely be present in a multiseptate gallbladder, wall thickening and pericholecystic fluid are not observed (9).

USG, computed tomography, MRCP, endoscopic retrograde cholangio-pancreatography, hepatobiliary scintigraphy, and oral-IV cholecystography are investigations and procedures that can be used in the differential diagnosis (10-12). Septations, linear internal echogenicities in the gallbladder lumen, and a honeycomb appearance are observed on USG (13). The appearance of a bunch of grapes in the gallbladder on MRCP is interpreted as multiseptate gallbladder. Using a combination of USG and MRCP is the best noninvasive imaging choice in the differential diagnosis of multiseptate gallbladder.

Multiseptate gallbladder is a biliary tract anomaly rarely seen in children. It is a rare pathology that should be considered in the differential diagnosis in addition to acute calculous cholecystitis and acalculous cholecystitis in pediatric patients with recurrent right upper quadrant pain. Cholecystectomy is curative in symptomatic cases. Follow-up with USG is recommended in asymptomatic cases.

\section{Authorship Contributions}

Surgical and Medical Practices: C.I.Ö., E.Ş., R.D., C.K.T. Concept: A.Ş. Design: M.N.A. Data Collection or Processing:
C.I.Ö., S.A.B., E.K. Analysis or Interpretation: M.N.A., E.Ş. Literature Search: A.Ş., C.I.Ö. Writing: C.I.Ö.

Conflict of Interest: No conflict of interest was declared by the authors.

Financial Disclosure: The authors declared that this study received no financial support.

\section{References}

1. Simon M, Tandon BN. Multiseptategallbladder. Radiology 1963;80:84-6.

2. Rivera-Troche $E Y$, Hartwig MG, Vaslef $S N$. Multiseptategallbladder. J Gastrointest Surg 2009;13:1741-3.

3. Wanaguru D, Jiwane A, Day AS, Adams S. Multiseptate Gallbladder in an Asymptomatic Child. Case Rep Gastrointest Med 2011;2011:470658.

4. Meilstrup JW, Hopper KD, Thieme GA. Imaging of gallbladder variants. AJR Am J Roentgenol 1991;157:1205-8.

5. Dalgıç B, Özbay F, Boyunağa Ö. Multiseptate Gallbladder With Recurrent Abdominal Pain and Elevated Liver Enzymes in A Child. Gazi Medical Journal 2003:14:39-40.

6. Paciorek ML, Lackner D, Daly C, Sekas G. A unique presentation of multiseptate gallbladder. Dig Dis Sci 1997;42:2519-23.

7. Wales LR. Desquamated gallblader mucosa:unusual sign of cholecystitis. AJR Am J Roentgenol 1982;139:810-1.

8. Sugawara T, Kamei M, Sato M, Suzuki K, Okada N, Ono S. Three cases of multiseptate gallbladder. Nihon Geka Gakkai Zasshi 2001;102:358-62.

9. Lev-Toaff AS, Friedman AC, Rindsberg SN, Caroline DF, Maurer AH, Radecki PD. Multiseptate gallbladder: incidental diagnosis on sonography. AJR Am J Roentgenol 1987;148:1119-20.

10. Konishi F, Saito H, Asano A. A case report of multiseptate gallbladder. Nihon Shokakibyo Gakkai Zasshi 1975;72:1252-6.

11. Nakajima M, Nakayama M, Saito H, Sasaki H, Nomura F. A case of multiseptate gallbladder. Nihon Shokakibyo Gakkai Zasshi 1978;75:381-5.

12. Okuda K, Nakajima M, Nakayama M, Nomura F. Multiseptate gallbladder ;Report of a case with a review of literature. Acta Hepatogastroenterol (Stuttg) 1979;26:70-5.

13. Saddik D. Multiseptategall-bladder: incidental diagnosis on Ultrasound. Austras Radiol 1998;42:374-6. 